\title{
AN INVESTIGATION OF THE PHARMACOKINETICS AND POTENTIAL METABOLITES OF POTASSIUM 2-((4-AMINO-5- (MORFOLINOMETYL)-4H-1,2,4-TRIAZOL-3-YL)THIO) ACETATE ON RATS
}

\author{
POTASYUM 2-((4-AMINO-5-(MORFOLINOMETIL)-4H-1,2,4-TRIAZOL-3-IL)TIYO) \\ ASETATIN FARMAKOKINETİĞI VE POTANSIYYEL METABOLITLLERININ SIÇANLARDA \\ ARAŞTIRILMASI
}

Roman SHCHERBYNA*

Zaporizhzhya State Medical University, Faculty of Pharmacy, Department of Natural Sciences for Foreign Students and Toxicological Chemistry, 69035, Zaporizhzhya, Ukraine

\begin{abstract}
Objective: The purpose of this work is to study the designated pharmacokinetic parameters and possible metabolites of the substance potassium 2-((4-amino-5-(morfolinometyl)-4H-1,2,4-triazol-3-yl)thio)acetate by intragastric introduction to rats.

Material and Method: The study was performed on Wistar rats. The following parameters were calculated to evaluate the pharmacokinetic properties: area under the pharmacokinetic curve (AUC), apparent clearance $(C L)$, elimination rate constant $(K)$, volume of distribution $(V T)$, serum half-life (t1/2). Separation was performed using Agilent 1260 Infinity HPLC system.

Result and Discussion: The determination of the concentration of potassium 2-((4-amino-5(morfolinometyl)-4H-1,2,4-triazol-3-yl)thio)acetate in serum was performed for 0.08 (5 min), 0.25 (15 min), 0.75 (45 $\mathrm{min}), 2.5,7.5,13.5$ and 24 hours. It was found that in the serum of rats the maximum concentration of the injected substance was reached almost immediately after administration, namely for 5 min with an average value at the level of 279,67 $\mu \mathrm{g} / \mathrm{ml}$. Thereafter, the concentration decreases mono-exponential, which indicates that the distribution and elimination occur at the same rate. The area under the pharmacokinetic curve is AUC $=150,8998 \mu \mathrm{g} * \mathrm{~h} / \mathrm{ml}$. The serum half-life of the specified substance is established $(\mathrm{t} 1 / 2=0.32$ hours $)$. Based on the obtained chromatograms and mass spectra, 5 possible metabolites of potassium 2-((4-amino-5(morfolinometyl)-4H-1,2,4-triazol-3-yl)thio)acetate (PKR-173)were determined by intragastric introduction to rats.
\end{abstract}

Keywords: 1,2,4-triazole, metabolite, pharmacokinetics

\footnotetext{
* Corresponding Author/Sorumlu Yazar: Roman Shcherbyna e-mail/e-posta: rscherbyna@gmail.com, Phone / Tel.: +380979181933
} 


\section{$\ddot{\mathbf{O Z Z}}$}

Amaç: Bu çalışmanın amacı, sıçanlara intragastrik olarak uygulanan potasyum 2-((4-amino-5(morfolinometil)-4H-1,2,4-triazol-3-il)tiyo) asetat maddesinin, belirli farmakokinetik parametrelerini ve olasl metabolitlerini incelemektir.

Gereç ve Yöntem: Çalışma Wistar sıçanları üzerinde gerçekleştirilmiştir ve farmakokinetik özellikleri değerlendirmek için aşă̆ldaki parametreler hesaplanmıştır: Farmakokinetik ĕgri altındaki alan (AUC), toplam klerens (CL), eliminasyon sabiti (K), toplam dağılım hacmi (VT) ve serum yarlanma ömrü (t1/2). Ayırım, Agilent 1260 Infinity HPLC sistemi kullanılarak gerçekleştirilmiştir.

Sonuç ve Tartışma: Kan serumundaki potasyum 2-((4-amino-5-(morfolinometil)-4H-1,2,4-triazol-3il)tiyo) asetat konsantrasyonunun belirlenmesi, 0.08 (5 dakika), 0.25 (15 dakika), 0.75 (45 dakika), 2.5, 7.5, 13.5 ve 24 saat boyunca gerçekleştirilmiştir. Siçanların kan serumunda, enjekte edilen maddenin maksimum konsantrasyonuna, uygulamadan hemen sonra, ortalama $279.67 \mu \mathrm{g} / \mathrm{ml}$ lik bir değerle ve 5 dakika içinde ulaşıldığı bulunmuştur. Bu aşamadan sonra, konsantrasyon mono-exponential olarak azalmıştır ve bu durum dă̆ılım ve eliminasyonun aynı oranda devam ettiğini göstermiş̧tir. Farmakokinetik ĕ̆ri altındaki alan (AUC) $=150.8998 \mu \mathrm{g} * \mathrm{~h} / \mathrm{ml}$ olup, belirtilen maddenin serum yarlanma ömrü belirlenmiştir $(t 1 / 2=0,32$ saat $)$. Elde edilen kromatogramlara ve kütle spektrumlarına dayanarak, slçanlara intragastrik uygulama sonucunda, 5 adet olasi potasyum 2-((4-amino-5-(morfolinometil)-4H-1,2,4-triazol-3-il)tiyo) asetat metaboliti belirlenmiştir.

Anahtar Kelimeler: 1,2,4-triazol, farmakokinetik, metabolitler

\section{INTRODUCTION}

The process of creating new drugs is a rather complicated and time-consuming algorithm, as pharmacological documentation should include a large body of research into the effects of a potential drug on the human body $[1,2]$. Along with studies of specific activity for a potential drug, it is necessary to study acute and chronic toxicity without which it is not possible to objectively evaluate the safety of the drug [3]. In this respect, the pharmacokinetics is closely interrelated with toxicity, which allows scientists to fundamentally approach the development of dosage, route of administration, and emergency assistance (in overdose) with new drugs. Also, the study and establishment of metabolites of drugs plays an important role in establishing the mechanism of action of the drug and allows to predict the possible side effects [1-3].

The pharmaceutical industry, along with synthetic chemists for over 150 years, has been involved in the creation of diverse organic molecules with pronounced pharmacological properties [4-6]. 1,2,4Triazole derivatives are a prime example of this trend [7-11]. The range of use of molecules containing this nucleus is very wide [12-14]. In our previous studies, the potential substances of potassium 2-((4amino-5-(morfolinometyl)-4H-1,2,4-triazol-3-yl)thio)acetate (PKR-173) as a hepatoprotector and antioxidant was noted $[15,16]$. Therefore, the purpose of this work is to study the pharmacokinetic parameters and possible metabolites of this substance by intragastric introduction to rats. 


\section{MATERIAL AND METHOD}

The starting material of potassium 2-((4-amino-5-(morfolinometyl)-4H-1,2,4-triazol-3-yl)thio) acetate (PKR-173) was synthesized and standardized by the methods described previously [17, 18]. All studies were approved by the Bioethics Committee of Zaporizhzhya State Medical University (protocol № 1 of 10/01/2019).

\section{Biological part}

The studies were performed on pubescent white nonlinear rats (Wistar) of both sexes weighing 107-246 g. The rats were obtained from the nursery of the State Institution of Pharmacology and Toxicology (Academy of Medical Sciences of Ukraine). During the experiment, the animals were restricted from food access and water was not restricted. A substance of potassium 2-((4-amino-5(morfolinometyl)-4H-1,2,4-triazol-3-yl)thio)acetate (PKR-173) was orally administered in an isotonic solution using a rigid probe. Rats were removed from the experiment by anesthesia with diethyl ester and blood was collected from aortic bifurcation. The blood was centrifuged, serum was isolated. A number of parameters have been calculated to evaluate the pharmacokinetic properties of PKR-173.

The area under the pharmacokinetic curve "concentration-time" (AUC) is the main pharmacokinetic parameter characterizing the bioavailability of a medicinal product and is calculated by the formula:

$$
A U C=\frac{C_{1}}{2} * \Delta t_{1}+\frac{C_{1}+C_{2}}{2} * \Delta t_{2}+\frac{C_{2}+C_{3}}{2} * \Delta t_{3}+\ldots+A U C_{r e m}(\mathrm{mg} * \mathrm{~h} / \mathrm{L})
$$

where, AUCrem - is the ratio of the last determination of the compound concentration to the elimination constant.

Apparent clearance (CL) reflects a volume of serum from which drug is completely removed per unit of time, where (D) represents the Dose:

$$
C L=\frac{D}{A U C}(m l / h)
$$

Elimination rate constant $(\mathrm{K})$, characterizing the decrease in the concentration of the drug at the end of the pharmacokinetic curve:

$$
K=\frac{\ln \frac{C_{\max }}{C_{\text {rem }}}}{T_{\text {rem }}-T_{\max }}\left(h^{-1}\right)
$$

where, $\boldsymbol{C}_{\boldsymbol{m a x}}$ and $\boldsymbol{T}_{\boldsymbol{m a x}}$ - are the maximum concentration and time of this determination;

$\boldsymbol{C}_{\boldsymbol{r} e m}$ and $\boldsymbol{T}_{\boldsymbol{r} e m}$ - recent concentration and study time values.

Volume of distribution (VT), is the theoretical volume that would be necessary to contain the total amount of an administered drug at the same concentration that it is observed in the blood plasma:

$$
V_{T}=\frac{C L}{K}(m l)
$$


Biological half-life (t1/2), showing the time during which the concentration of the test substance in the blood is halved:

$$
t_{1 / 2}=\frac{\ln 2}{K}(h)
$$

\section{Chromatographic conditions}

Separations were carried out using an Agilent 1260 Infinity HPLC System (Agilent Technologies, Germany) system consisting of a degasser, binary pump, autosampler, thermostat column compartment, and diode array detector. Data acquisition was performed using the Open LAB CDS Software. The column was ZORBAX RX-SIL $(50 \times 4.6,1.8 \mu \mathrm{m})$. The column temperature was maintained at $40 \mathrm{oC}$. The mobile phase consisted of $70 \%$ acetonitrile $(0.1 \% \mathrm{HCOOH}): 30 \% \mathrm{H} 2 \mathrm{O}$ (100mM HCOONH4). The flow rate of the mobile phase was $0.400 \mathrm{ml} / \mathrm{min}$.

The injected volume was $20 \mu \mathrm{l}$ for metabolite identification and $2 \mu \mathrm{l}$ for pharmacokinetics study.

\section{Mass spectrometry conditions}

Agilent 6120 single quadrupole mass spectrometer with ionization in electrospray (ESI) was utilized. Scanning was performed in the range of m/z 100-1000 for metabolite identification. SIM mode for pharmacokinetics study was at m/z 274 and m/z 547. The MS "fragmentor" voltage was 10V with positive polarity. Drying gas temperature was $300 \mathrm{oC}$. Nebulizer pressure was 40 psi. Drying gas flow rate was $10 \mathrm{l} / \mathrm{min}$

\section{Sample preparation}

For analyses, $100 \mu \mathrm{l}$ of plasma sample was added to $2.0-\mathrm{mL}$ Eppendorf polypropylene centrifuge micro-tube. Then, $1 \mathrm{ml}$ of methanol was added to the tube. Tube was mixed. After, $20 \mu \mathrm{l}$ of $60 \%$ perchloric acid was added, it was shaken on a vortex mixer for 1 minute, and ultrasonicated for 3 minutes. The mixture was centrifuged for 10 minutes at $15000 \mathrm{~g}$. Supernatant was injected to LC-MS.

\section{RESULT AND DISCUSSION}

\section{The biological part}

Determination of the concentration of PKR-173 was carried out for 24 hours, and the preliminary determination time was calculated from the logarithm 24 on the basis of 10 at an interval of 0,5 (Table 1). 
Table 1. Calculation of the time of blood collection after administration of potassium 2-((4-amino-5(morfolinometyl)-4H-1,2,4-triazol-3-yl)thio)acetate

\begin{tabular}{|l|l|l|l|l|l|l|}
\hline Time & 24 & & & & & \\
\hline $\lg _{10}$ (hour) & 1,38 & 0,88 & 0,38 & $-0,12$ & $-0,62$ & $-1,12$ \\
\hline $10^{\log _{10} \text { (hour) }}$, hour & 24 & 7,59 & 2,4 & 0,76 & 0,24 & 0,08 \\
\hline
\end{tabular}

Since the time intervals are too small, a logarithmic scale was used. Thus, based on the data obtained, the determination of the concentration of potassium 2-((4-amino-5-(morfolinometyl)- $4 \mathrm{H}-1,2,4-$ triazol-3-yl)thio)acetate in serum was performed for 0.08 (5 $\mathrm{min}), 0.25$ (15 $\mathrm{min}), 0.75$ (45 $\mathrm{min}), 2.5,7.5$, 13.5 and 24 hours.

In this way, as a result of the study, it was found that in the serum of rats the maximum concentration of the administered substance was reached almost immediately after the introduction, namely for $5 \mathrm{~min}$ with an average value at the level of $279,67 \mu \mathrm{g} / \mathrm{ml}$ (Table 2).

Table 2. Concentration of potassium 2-((4-amino-5-(morfolinometyl)-4H-1,2,4-triazol-3-yl)thio) acetate in blood, $\mu \mathrm{g} / \mathrm{ml}$

\begin{tabular}{|l|l|l|l|l|l|l|l|}
\hline $\mathbf{C}, \boldsymbol{\mu g} / \mathbf{m l}$ & 279,6703 & 275,2029 & 68,04355 & 0 & 0 & 0 & 0 \\
\hline Time, h & 0,08 & 0,25 & 0,75 & 2,5 & 7,5 & 13,5 & 24 \\
\hline
\end{tabular}

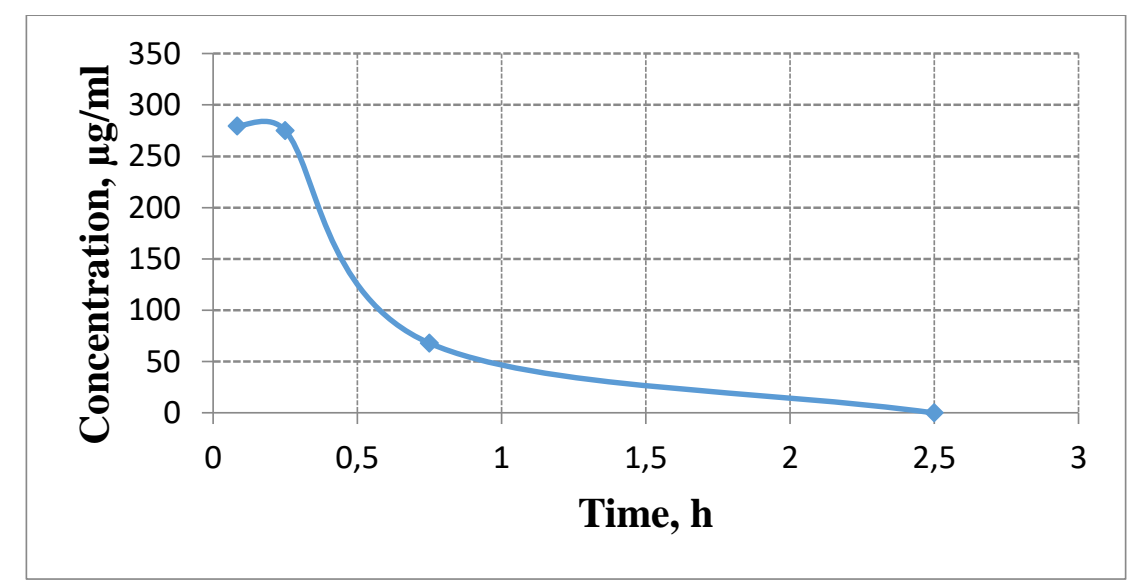

Figure 1. The concentration of potassium 2-((4-amino-5-(morfolinometyl)-4H-1,2,4-triazol-3yl)thio)acetate in the blood depending on time

As a result of the experiment, the arithmetic mean values of the potassium concentration of 2-((4amino-5-(morfolinometyl)-4H-1,2,4-triazol-3-yl)thio)acetate in the blood of rats were determined. Thus, from the data given in table 2 and figure 1, it was shown that the maximum concentration of the test compound was observed as early as 5 minutes after its administration to animals. Thereafter, the concentration decreases mono-exponentially, indicating that the distribution and elimination occur at the 
same rate. The main pharmacokinetic parameters calculated from the concentration of compound in plasma of rats over time (Table 3) show a low serum half-life (t1/2 $=0.32$ hours). The area under the pharmacokinetic curve is AUC $=150.8998 \mu \mathrm{g} * \mathrm{~h} / \mathrm{ml}$.

Table 3. Pharmacokinetic parameters of the substance potassium 2-((4-amino-5- (morfolinometyl)-4H1,2,4-triazol-3-yl)thio) acetate

\begin{tabular}{|l|l|}
\hline \multicolumn{1}{|c|}{ Indicator } & \multicolumn{1}{c|}{ Value } \\
\hline AUC, $\mu \mathrm{g} * \mathrm{~h} / \mathrm{ml}$. & 150,8998 \\
\hline AUCrem & 32,25353 \\
\hline $\ln (\mathrm{Cmax} / \mathrm{Crem})$ & 1,413463 \\
\hline $\mathrm{K}, \mathrm{h}-1$ & 2,109647 \\
\hline $\mathrm{t} 1 / 2, \mathrm{~h}$ & 0,328561 \\
\hline $\mathrm{CL}, \mathrm{ml} / \mathrm{h}$ & 1,086814 \\
\hline $\mathrm{VT}, \mathrm{l} / \mathrm{kg}$ & 0,515164 \\
\hline
\end{tabular}

\section{Chromatographic studies}

Subsequently, for the determination of possible metabolites of potassium 2-((4-amino-5(morfolinometyl)-4H-1,2,4-triazol-3-yl)thio)acetate, a chromatographic study was performed by liquid plasma chromatography of rats. Thus, on the chromatogram obtained at the 5 th minute of the introduction of the compound there is a peak with a retention time of $2.008 \mathrm{~min}$. In the mass spectrum of this peak there is a pseudo-molecular ion with a mass of $288.2 \mathrm{~m} / \mathrm{z}$. (Figure 2).
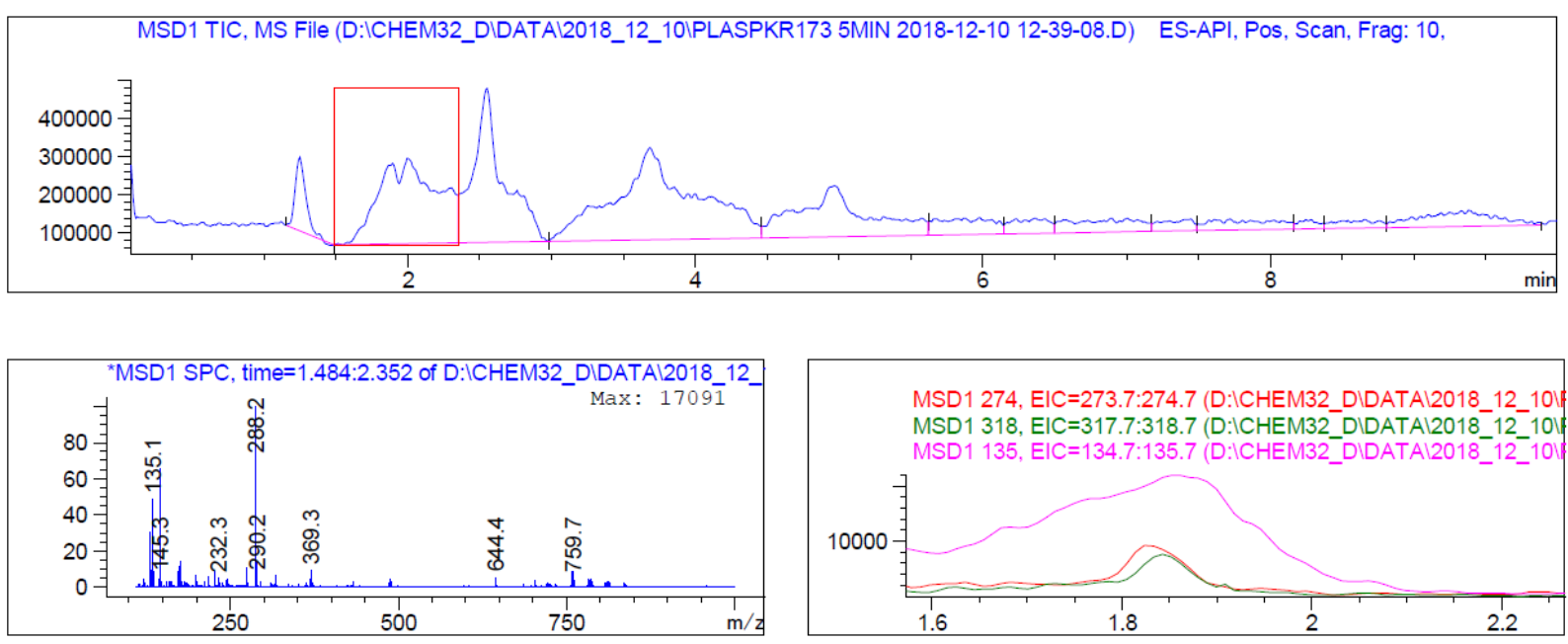

Figure 2. Chromatogram and mass spectrum of rat plasma with potassium 2-((4-amino-5(morfolinometyl)-4H-1,2,4-triazol-3-yl)thio)acetate (5 min). 
Further exploring possible metabolites, it should be noted, that the chromatogram obtained after $15 \mathrm{~min}$. introduction of the test substance there is contained an identical peak at $2.012 \mathrm{~min}$. In the mass spectrum, there is a molecular ion with a mass of $288.1 \mathrm{~m} / \mathrm{z}$. (Figure 3 ).
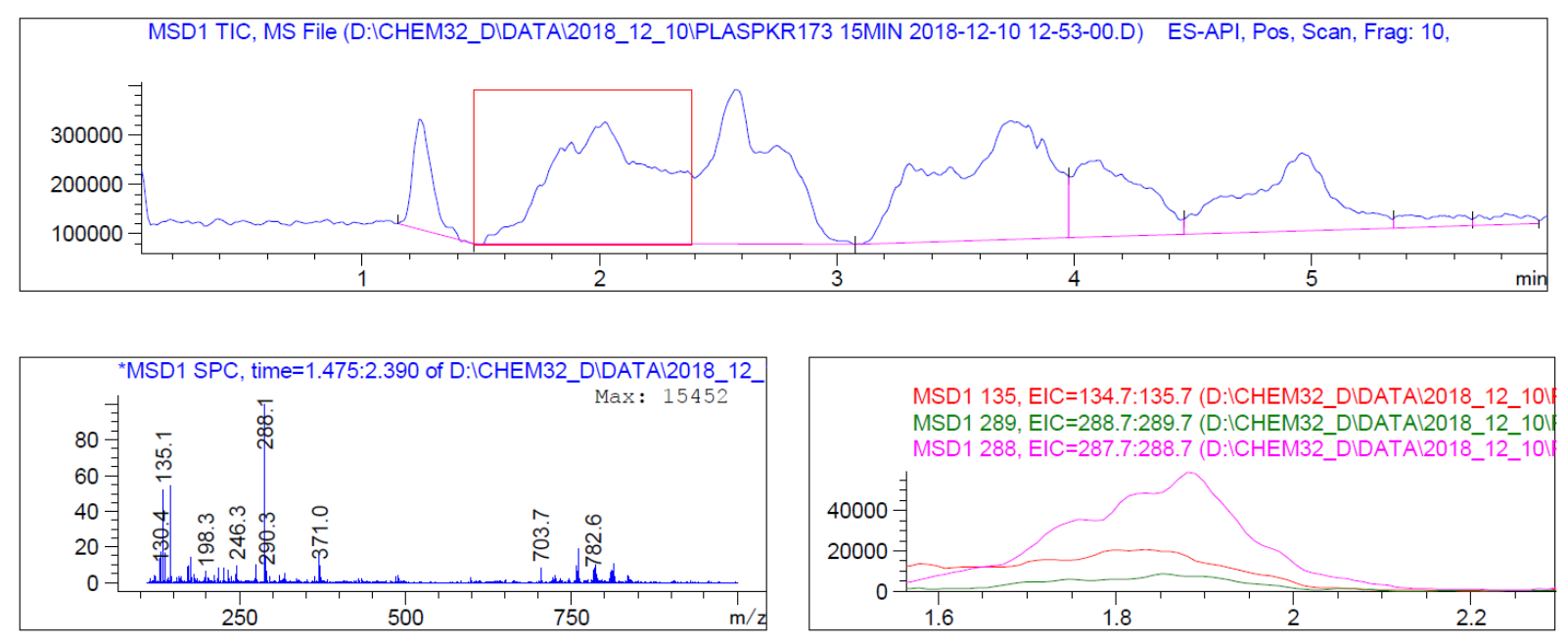

Figure 3. Chromatogram and mass spectrum of rat plasma with potassium 2-((4-amino-5(morfolinometyl)-4H-1,2,4-triazol-3-yl)thio)acetate (15 min).

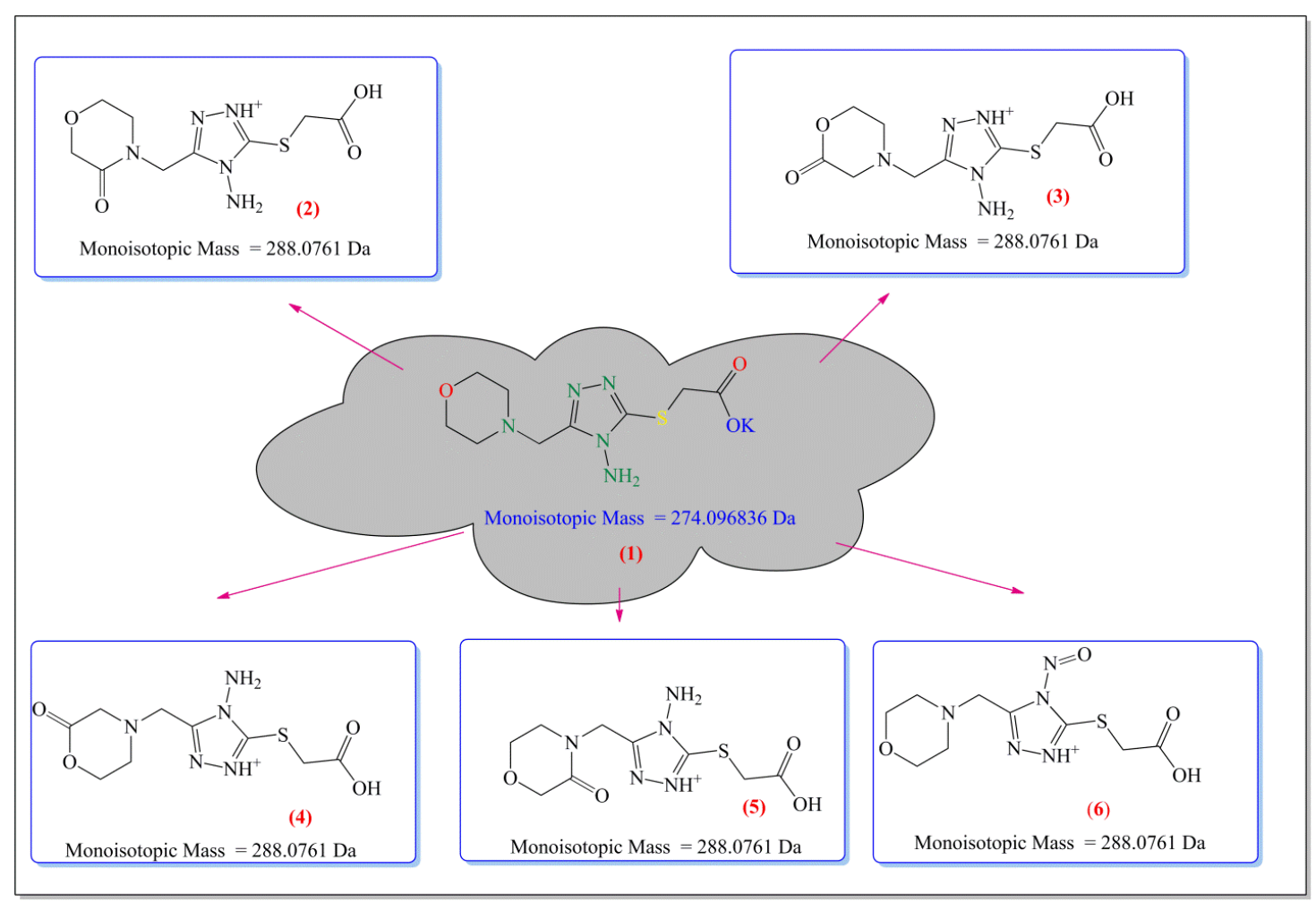

Figure 4. Scheme of formation of possible metabolites of potassium 2-((4-amino-5-(morpholinomethyl)4H-1,2,4-triazol-3-yl)thio)acetate compound 
The data obtained from chromatographic studies allowed us to determine the probable structures of metabolites based on obtaining the values of their molecular weights $(\mathrm{m} / \mathrm{z})($ Figure 4$)$ such as:

4-amino-5-((carboxymethyl)thio)-3-((3-oxomorpholino)methyl)-4H-1,2,4-triazol-1-ium(2),

4-amino-5 ((carboxymethyl)thio)-3-((2-oxomorpholino)methyl)-4H-1,2,4-triazol-1-ium(3),

4-amino-5-((carboxymethyl)thio)-3-((2-oxomorpholino)methyl)-4H-1,2,4-triazol-1-ium(4),

4-amino-5-((carboxymethyl)thio)-3-((3-oxomorpholino)methyl)-4H-1,2,4-triazol-1-ium(5),

5-((carboxymethyl)thio)-3-(morpholinomethyl)-4-nitroso-4H-1,2,4-triazol-1-ium (6).

In conclusion, the study of the pharmacokinetic parameters of potassium 2-((4-amino-5(morpholinomethyl)-4H-1,2,4-triazol-3-yl)thio)acetate (PKR-173) by intragastric introduction to rats was held. The serum half-life of named substance is established ( $\mathrm{t}_{1 / 2}=0.32$ hours). Based on the obtained chromatograms and mass spectra, possible metabolites of potassium 2-((4-amino-5-(morfolinometyl)-4H1,2,4-triazol-3-yl) thio) acetate (PKR-173) during intragastric introduction to rats were determined.

\section{REFERENCES}

1. Gerry, C. J., Schreiber, S. L. (2018). Chemical Probes And Drug Leads From Advances In Synthetic Planning And Methodology. Nature Reviews Drug Discovery, 17(5), 333.

2. Blumenthal, G. M., Goldberg, K. B., Pazdur, R. (2017). Drug development, trial design, and endpoints in oncology: adapting to rapidly changing science. Clinical Pharmacology \& Therapeutics, 101(5), 572-574.

3. Mohs, R. C., Greig, N. H. (2017). Drug discovery and development: Role of basic biological research. Alzheimer's \& Dementia: Translational Research \& Clinical Interventions, 3(4), 651657.

4. Shcherbyna, R. O. (2014). Pharmacological Activity Analysis Of The 1,2,4-Triazole Derivatives. Pharmaceutical Journal, (4), 145-150.

5. Kumar, R., Yar, M. S., Chaturvedi, S., Srivastava, A. (2013). Triazole as pharmaceuticals potentials. Inter J Pharm Tech Res, 5(4), 1844-1869.

6. Peyton, L. R., Gallagher, S., Hashemzadeh, M. (2015). Triazole antifungals: a review. Drugs Today (Barc), 51(12), 705-718.

7. Bushueva, I., Parchenko, V., Shcherbyna, R., Safonov, A., Kaplaushenko, A., Gutyj, B., Hariv, I. (2017). Tryfuzol-New Original Veterinary Drug. J. Fac. Pharm. Ankara/Ankara Ecz. Fak. Derg, 41(1), 42-49.

8. Shcherbyna, R. O., Danilchenko, D. M., Parchenko, V. V., Panasenko, O. I., Knysh, E. H., Hromyh, N. A., Lyholat, Y. V. (2017). Studying Of 2-((5-R-4-R-1-4H-1,2,4-triazole-3yl)thio)acetic Acid Salts Influence On Growth And Progress Of Blackberries (KIOWA Variety) Propagules. Research Journal of Pharmaceutical Biological and Chemical Sciences, 8(3), 975979. 
9. Hulina, Y.S., Kaplaushenko, A. G. (2018). Synthesis, Physicochemical Properties And Further Transformations In The Series 5-((1H-tetrazol-1-yl)methyl)-4-R-4H-1,2,4-triazol-3-thiols. Biopharmaceutical Journal, 10 (1), 26-30.

10. Samelyuk, Y. G., Kaplaushenko, A. G. (2014). Synthesis of 3-alkylthio(sulfo)-1,2,4-triazoles, Containing methoxyphenyl substituents at C5atoms, Their antipyretic activity, Propensity to adsorption and acute toxicity. Journal of Chemical and Pharmaceutical Research, 6(5), 11171121.

11. Keri, R. S., Patil, S. A., Budagumpi, S., Nagaraja, B. M. (2015). Triazole: a promising antitubercular agent. Chemical biology \& drug design, 86(4), 410-423.

12. Shcherbyna, R., Parchenko, V., Martynyshyn, V., Hunchak, V. (2018). Evaluation Of Acute And Subacute Toxicity Of Oil Liniment Based On 4-((5-(Decylthio)-4-methyl-4H-1,2,4-triazol3-yl)methyl)morpholine. J. Fac. Pharm. Ankara/Ankara Ecz. Fak. Derg, 42 (1), 43-52. Retrieved from http://dergipark.gov.tr/jfpanu/issue/42653/514314.

13. Safonov, A. A. (2018). Derivatives of 3-(alkylthio)-5-(thiophen-2-ylmethyl)-4H-1, 2, 4-triazol4-amines as Anti-fatigue Substances. Indonesian Journal of Pharmacy/Majalah Farmasi Indonesia, 29(3).

14. Küçükgüzel, Ş. G., Çıkla-Süzgün, P. (2015). Recent advances bioactive 1,2,4-triazole-3thiones. European journal of medicinal chemistry, 97, 830-870.

15. Shcherbyna, R., Vashchyk, Y. (2019). The Research Of 1,2,4-Triazole Derivatives Hepatoprotective Activity Under Tetracycline And Infectious Hepatitis. Journal of Faculty of Pharmacy of Ankara University, 43 (2), 135-146 . DOI: 10.33483/jfpau.487173

16. Shcherbyna, R.O., Vashchyk, Y.V. (2018). Histological study of potassium 2-((4-amino-5(morpholinomethyl)-4H-1, 2, 4-triazole-3-yl)thio)acetate (PKR-173) corrective influence on the chickens liver state in the condition of tetracycline hepatitis. Zaporožskij Medicinskij Žurnal, 3, 404-412.

17. Shcherbyna, R., Parchenko, V., Varynskyi, B., Kaplaushenko, A. (2019). The development of HPLC-DAD method for determination of active pharmaceutical ingredient in the potassium 2((4-amino-5-(morpholinomethyl)-4H-1, 2, 4-triazol-3-yl) thio) acetate substance. Current Issues in Pharmacy and Medical Sciences, 32(1), 5-9.

18. Shcherbyna, R. O. (2017). Synthesis, physical and chemical properties of 2-((4-R-3(morfolinomethylen)-4H-1,2,4-triazole-5-yl)thio)acetic acid salts. Current Issues in Pharmacy and Medicine: Science and Practice, 10 (1), 4-8. 